\title{
Hubungan pola konsumsi minuman beralkohol terhadap kejadian hipertensi pada tenaga kerja pariwisata di Kelurahan Legian
}

\author{
I Gusti Ayu Ninik Jayanti", Ni Ketut Wiradnyani, I Gede Ariyasa
}

\begin{abstract}
Background: The shift in lifestyle in tourism environment in Legian Village triggers alcohol consumption. Excessive consumption of alcoholic beverages will have an impact on long-term health of one of them increased levels of cortisol in the blood so that the activity of rennin-angiotensin aldesterol system (RAAS) increases and causes blood pressure to rise.

Objectives: To determine the correlation between consumption patterns of alcoholic beverage with incidence of tourism labor hypertension in Legian.

Methods: Design of crossectional study with sample of 87 tourism worker. Blood pressure measurement using Sphygmomanometer and stethoscope. The consumption pattern of alcoholic beverages is obtained by using the form of $S Q-F F Q$ (Semi Quantitative Food Frequency Qualitiative).

Results: The most common type of alcoholic beverage is beer with a percentage of $40.2 \%$. A total of $48.3 \%$ of respondents consumed alcoholic beverages with a mild amount and as much as $56.3 \%$ of respondents often consumed alcoholic beverages. There was a significant correlation between beverage type and hypertension $\left(r_{s}=0.433\right)$, total consumption and hypertension $\left(r_{s}=0.566\right)$.

Conclusion: There was a significant correlation between consumption pattern of alcoholic beverages with incidence of hypertension in tourism labor in Legian Village
\end{abstract}

Keywords : consumption pattern of alcoholic beverage; hypertension incidence; tourism workers

\begin{abstract}
ABSTRAK
Latar Belakang : Pergeseran gaya hidup di lingkungan pariwisata di Kelurahan Legian memicu konsumsi alkohol. Konsumsi minuman beralkohol secara berlebihan akan berdampak pada kesehatan jangka panjang salah satunya peningkatan kadar kortisol dalam darah sehingga aktivitas rennin-angiotensin aldesterol system (RAAS) meningkat dan menyebabkan tekanan darah meningkat.

Tujuan : Menjelaskan hubungan pola konsumsi minuman beralkohol terhadap kejadian hipertensi pada tenaga kerja pariwisata di Kelurahan Legian.

Metode : Desain penelitian crossectional study dengan jumlah sampel 87 tenaga kerja pariwisata. Pengukuran tekanan darah menggunakan sphygmomanometer dan stetoskop. Pola konsumsi minuman beralkohol diperoleh dengan menggunakan instrument yaitu berupa form SQ-FFQ (Semi Quantitative Food Frequency Qualitiative.

Hasil : Jenis minuman beralkohol yang paling banyak dikonsumsi adalah beer dengan persentase 40,2\%. Sebanyak 48,3\% responden mengkonsumsi minuman beralkohol dengan jumlah ringan dan sebanyak 56,3\% responden sering mengkonsumsi minuman beralkohol. Terdapat hubungan yang signifikan antara jenis minuman dan kejadian hipertensi $\left(r_{s}=0,433\right)$, jumlah konsumsi dan kejadian hipertensi $\left(r_{s}=0,566\right)$.

Kesimpulan : Terdapat hubungan yang signifikan antara pola konsumsi minuman beralkohol dengan kejadian hipertensi pada tenaga kerja pariwisata di Kelurahan Legian.
\end{abstract}

Kata Kunci : pola konsumsi minuman beralkohol; kejadian hipertensi; tenaga kerja pariwisata

\section{PENDAHULUAN}

Bali sebagai kota tujuan wisata menjadikan perkembangan tempat hiburan semakin pesat. Salah satu dampak positif dengan adanya tempat hiburan tersebut adalah peningkatan pendapatan dan tersedianya lapangan pekerjaan bagi masyarakat Bali. Walaupun demikian, terdapat dampak negatif yang muncul seperti konsumsi alkohol pada pekerja pariwisata sebagai akibat dari pergeseran gaya hidup di

Program Studi Ilmu Gizi, Fakultas Ilmu Kesehatan, Sains dan Teknologi, Universitas Dhyana Pura. Jln. Raya Padang Luwih, Tegaljaya, Dalung, Badung-Bali.

* Korespondensi : ninikjayanti52@gmail.com lingkungan pariwisata perkotaan. Jumlah tenaga kerja pariwisata yang ada di Kelurahan Legian cukup banyak yaitu 640 orang pada tahun 2016.

Konsumsi minuman alkohol secara berlebihan akan berdampak buruk pada kesehatan jangka panjang. Salah satu akibat dari konsumsi alkohol yang berlebihan tersebut adalah terjadinya peningkatan tekanan darah yang disebut hipertensi. Alkohol merupakan salah satu penyebab hipertensi karena alkohol memiliki efek yang sama dengan karbondioksida yang dapat meningkatkan keasaman darah, sehingga dalah menjadi kental dan jantung dipaksa untuk memompa ${ }^{1}$, selain itu konsumsi alkohol yang berlebihan dalam jangka panjang akan berpengaruh pada peningkatan kadar kortisol dalam 
darah sehingga aktifitas rennin-angiotensin aldosteron system (RAAS) meningkat dan mengakibatkan tekanan darah meningkat. ${ }^{2}$ Prevalensi hipertensi di Provinsi Bali cukup tinggi yaitu $12,2 \%{ }^{3}$

Beberapa penelitian menyatakan bahwa terdapat hubungan yang erat antara lama, frekuensi serta jenis alkohol yang dikonsumsi dengan kejadian hipertensi. Penelitian pada laki-laki di Desa Kompasobaru II Kecamatan Tompasobaru Kabupaten Minahasa Selatan menyatakan ada hubungan antara lama, frekuensi dan jenis alkohol dengan kejadian hipertensi 1. Selain itu terdapat hubungan antara konsumsi alkohol dengan hipertensi di wilayah puskesmas Langsot Kota Tomohon. ${ }^{4}$ Demikian juga penelitian yang dilakukan di Desa Okawdua Kecamatan Sinonsayang Kabupaten Minahasa Selatan juga terdapat hubungan antara konsumsi alkohol dengan kejadian hipertensi. ${ }^{5}$ Oleh karena itu perlu dilakukan penelitian tentang hubungan pola konsumsi minuman beralkohol terhadap kejadian hipertensi pada tenaga kerja pariwisata di Kelurahan Legian.

\section{BAHAN DAN METODE}

Desain penelitian ini adalah cross sectional. Penelitian ini dilaksanakan mulai bulan April-Mei 2017 di hotel, cafe dan bar yang berada Kelurahan Legian. Subjek penelitian sesuai dengan kriteria inklusi yaitu tenaga kerja pariwisata di Kelurahan Legian berumur diatas 17-50 tahun yang mengkonsumsi alkohol, bersedia menjadi respoden penelitian, berpendidikan minimal SMA. Subjek berjumlah 87 orang diambil dengan cara purposive sampling.

Pengukuran tekanan darah menggunakan sphygmomanometer dan stetoskop. Pola konsumsi minuman beralkohol pada penelitian ini diperoleh dengan menggunakan instrumen berupa form SQ-FFQ (Semi Quantitative Food Frequency Qualitiative). Kuisioner SQ-FFQ (Semi Quantitative Food Frequency Qualitiative) memuat beberapa pertanyaan berkaitan dengan pola konsumsi minuman beralkohol yang dilakukan dengan wawancara langsung pada responden. Dari pengolahan data pada kuisioner diperoleh data mengenai jenis minuman beralkohol yang dikonsumsi, jumlah yang dikonsumsi, serta frekuensi yang dikonsumsi oleh responden. Data dianalisis dengan menggunakan uji Rank Spearman yang digunakan untuk mengetahui hubungan antara pola konsumsi minuman beralkohol dengan kejadian hipertensi.

\section{HASIL}

\section{Karakteristik Responden}

Karakteristik responden dilihat dari jenis kelamin, umur, pendidikan terakhir dan bagian pekerjaan. Berdasarkan hasil penelitian diketahui bahwa jumlah responden laki-laki sebanyak 77 orang $(88,5 \%)$ sedangkan perempuan sebanyak 10 orang $(11,5 \%)$. Sebagian besar responden yang mengkonsumsi minuman beralkohol berusia 17-25 tahun sebanyak 35 orang $(40,2 \%)$ dan memiliki pendidikan terakhir diploma yaitu sebanyak 44 orang $(50,6 \%)$. Berdasarkan bagian pekerjaan sebagian besar responden dalam penelitian ini bekerja di bagian bartender yaitu sebanyak 28 orang $(32,2 \%)$. Karakteristik responden disajikan pada Tabel 1.

Tabel 1. Karakteristik Responden Tenaga Kerja Pariwisata di Kelurahan Legian

\begin{tabular}{lcc}
\hline Jenis Kelamin & $\mathbf{N}$ & $\mathbf{( \% )}$ \\
Laki-laki & 77 & 88,5 \\
$\quad$ Perempuan & 10 & 11,5 \\
\hline$\quad$ Total & 87 & 100 \\
\hline Usia & & \\
17-25 Tahun & 35 & 40,2 \\
26-35 Tahun & 28 & 32,2 \\
36-45 Tahun & 18 & 20,7 \\
46-50 Tahun & 6 & 6,9 \\
\hline Total & 87 & 100 \\
\hline Pendidikan Terakhir & & \\
SMA & 36 & 41,4 \\
Diploma & 44 & 50,6 \\
Sarjana & 7 & 8 \\
\hline Total & 87 & 100 \\
\hline Bagian Pekerjaan & & \\
$\quad$ Waiter/waitress & 25 & 28,7 \\
Cook & 21 & 24,1 \\
Bartender & 28 & 32,2 \\
Security & 7 & 8,0 \\
Bellboy & 1 & 1,1 \\
$\quad$ Reseptionist & 5 & 5,7 \\
\hline Total & 87 & 100 \\
\hline
\end{tabular}

\section{Pola Konsumsi Minuman Beralkohol}

Jenis minuman beralkohol yang paling sering dikonsumsi masyarakat umum secara garis besar dibedakan menjadi beer, wine, dan spirits (brandy, whisky dan vodka). Selain itu minuman beralkohol tradisional yang dikonsumsi pula oleh responden dalam penelitian ini yaitu tuak dan arak. Jenis minuman yang paling banyak dikonsumsi responden adalah beer yaitu sebanyak 35 responden (40,2\%), sedangkan wine yang paling sedikit dikonsumsi yaitu sebanyak 3 responden (3,4\%). Hasil secara lebih lengkap tercantum pada Tabel 2 . 
Tabel 2. Jenis Minuman Beralkohol yang Dikonsumsi Tenaga Kerja Pariwisata di Kelurahan Legian

\begin{tabular}{ccc}
\hline Jenis Minuman Beralkohol & N & \% \\
\hline Beer & 35 & 40,2 \\
Wine & 3 & 3,4 \\
Spirits (brandy, whisky dan vodka) & 30 & 34,5 \\
Lainnya (tuak dan arak) & 19 & 21,8 \\
\hline Total & 87 & 100 \\
\hline
\end{tabular}

Sebanyak 42 responden (48,3\%) mengkonsumsi minuman beralkohol dengan kategori ringan $(0,20$ - 6 $\mathrm{ml})$, sedangkan sebanyak 18 responden $(20,7 \%)$ dengan kategori sedang $(6,30-29 \mathrm{ml})$. Adapun 27 responden $(31 \%)$ mengkonsumsi minuman alkohol dengan kategori berat (>29 ml) (Tabel 3). Sebanyak 49 responden $(56,3 \%)$ sering mengkonsumsi alkohol sedangkan 38 responden $(43,7 \%)$ tidak sering mengkonsumsi minuman beralkohol (Tabel 4). Sebagian besar responden sebanyak 53 orang $(60,95)$ mengkonsumsi minuman beralkohol kurang dari 5 tahun. Sisanya sebanyak 34 orang $(39,1 \%)$ mengkonsumsi minuman beralkohol lebih dari 5 tahun (Tabel 5).

Tabel 3. Konsumsi Minuman Alkohol Per Hari pada Tenaga Kerja Pariwisata di Kelurahan Legian

\begin{tabular}{lll}
\hline $\begin{array}{l}\text { Konsumsi Minuman Beralkohol } \\
\text { Per Hari }\end{array}$ & N & \% \\
\hline Ringan $(0,29 \mathrm{ml}-6 \mathrm{ml})$ & 42 & 48,3 \\
Sedang $(6,30 \mathrm{ml}-29 \mathrm{ml})$ & 18 & 20,7 \\
Berat $(>29 \mathrm{ml})$ & 27 & 31 \\
\hline Total & 87 & 100 \\
\hline
\end{tabular}

Tabel 4. Frekuensi Konsumsi Minuman Beralkohol pada Tenaga Kerja Pariwisata di Kelurahan Legian

\begin{tabular}{lcc}
\hline $\begin{array}{l}\text { Frekuensi Konsumsi Minuman } \\
\text { Beralkohol }\end{array}$ & N & \% \\
\hline $\begin{array}{l}\text { Sering } \\
\text { (3x seminggu atau lebih) }\end{array}$ & 49 & 56,3 \\
$\begin{array}{l}\text { Tidak Sering } \\
\text { (Kurang dari 3x seminggu) }\end{array}$ & 38 & 43,7 \\
\hline Total & 87 & 100 \\
\hline
\end{tabular}

Tabel 5. Lama Konsumsi Minuman Beralkohol pada Tenaga Kerja Pariwisata di Kelurahan Legian

\begin{tabular}{lcc}
\hline $\begin{array}{l}\text { Lama Konsumsi } \\
\text { Minuman Beralkohol }\end{array}$ & N & \% \\
\hline$\leq 5$ tahun & 53 & 60,9 \\
$>5$ tahun & 34 & 39,1 \\
Total & 87 & 100 \\
\hline
\end{tabular}

\section{Kejadian Hipertensi}

Hasil kejadian hipertensi menunjukkan bahwa sebagian besar responden sebanyak 39 responden $(44,8 \%)$ termasuk dalam kategori beresiko (prehipertensi), 33 responden $(37,9 \%)$ mempunyai tekanan darah normal dan 15 responden $(17,2 \%)$ yang mengalami kejadian hipertensi (Tabel 6).

Tabel 6. Kejadian Hipertensi Tenaga Kerja Pariwisata di Kelurahan Legian yang Mengkonsumsi Minuman Beralkohol

\begin{tabular}{lll}
\hline Kejadian Hipertensi & N & \% \\
\hline Normal & 33 & 37,9 \\
Berisiko (Prehipertensi) & 39 & 44,8 \\
Tinggi & 15 & 17,2 \\
\hline Total & 87 & 100 \\
\hline
\end{tabular}

Hubungan Jenis Minuman Beralkohol yang Dikonsumsi dengan Kejadian Hipertensi.

Berdasarkan Tabel 7 diketahui bahwa sebagian besar responden dalam penelitian ini mengkonsumsi minuman beralkohol jenis beer sebanyak $40,2 \%$. Hasil pengukuran tekanan darah menunjukkan responden yang minum beer dan wine sebagian besar mempunyai tekanan darah yang normal. Akan tetapi responden yang minum spirits dan minuman lainnya (tuak dan arak), sebagian besar mempunyai tekanan darah beresiko (prehipertensi). Secara keseluruhan sebagian besar responden yaitu sekitar 39 orang $(44,8 \%)$ mempunyai tekanan darah beresiko (prehipertensi). Berdasarkan uji korelasi sperman antara variabel jenis miuman beralkohol dengan hipertensi diketahui bahwa terdapat hubungan yang signifikan antara jenis minuman beralkohol yang dikonsumsi dan hipertensi dengan nilai $\mathrm{p}=0,000(\mathrm{p}<0,05)$ dengan korelasi yang kurang kuat yaitu 0,433 (Tabel 8).

Tabel 7. Kejadian Hipertensi Berdasarkan Jenis Minuman Beralkohol yang Dikonsumsi Tenaga Kerja Pariwisata Di Kelurahan Legian

\begin{tabular}{|c|c|c|c|c|c|c|c|c|}
\hline \multirow{3}{*}{ Jenis } & \multicolumn{8}{|c|}{ Kejadian Hipertensi } \\
\hline & \multicolumn{2}{|c|}{ Normal } & \multicolumn{2}{|c|}{ Beresiko (Prehipertensi) } & \multicolumn{2}{|c|}{ Tinggi } & \multicolumn{2}{|c|}{ Total } \\
\hline & $\mathbf{N}$ & $\%$ & $\mathbf{N}$ & $\%$ & $\mathbf{N}$ & $\%$ & $\mathbf{N}$ & $\%$ \\
\hline Beer & 22 & 25,3 & 11 & 12,6 & 2 & 2,3 & 35 & 40,2 \\
\hline Wine & 2 & 2,3 & 1 & 1,1 & 0 & 0 & 3 & 3,4 \\
\hline Spirits & 6 & 6,9 & 16 & 18,4 & 8 & 9,2 & 3 & 3,4 \\
\hline Lainnya (tuak dan arak ) & 3 & 3,4 & 11 & 12,6 & 5 & 5,7 & 19 & 21,8 \\
\hline Total & 33 & 37,9 & 39 & 44,8 & 15 & 17,2 & 87 & 100 \\
\hline
\end{tabular}


Tabel 8. Hasil Uji Korelasi Jenis Minuman Beralkohol yang Dikonsumsi dengan Kejadian Hipertensi pada Tenaga Kerja Pariwisata di Kelurahan Legian

\begin{tabular}{llll}
\hline $\begin{array}{l}\text { Variabel } \\
\text { independen }\end{array}$ & $\begin{array}{l}\text { Variabel } \\
\text { dependen }\end{array}$ & $\mathbf{r}_{\mathbf{s}}$ & p value \\
\hline Jenis minuman & $\begin{array}{l}\text { Kejadian } \\
\text { Hipertensi }\end{array}$ & 0,433 & 0,0001 \\
\hline
\end{tabular}

Hubungan Jumlah Konsumsi Minuman Beralkohol Dengan Kejadian Hipertensi

Berdasarkan Tabel 9, sebagian besar responden 28,3\% mengkonsumsi minuman beralkohol per hari dengan kategori ringan $(0,29 \mathrm{ml}-6 \mathrm{ml})$. Pada responden dengan konsumsi minuman beralkohol ringan mempunyai tekanan darah yang normal $(14,1 \%)$ dan beresiko (14,1\%). Responden dengan konsumsi minuman beralkohol sedang mempunyai tekanan darah normal (13,8\%) dan beresiko (6,9\%). Adapun responden yang mengkonsumi minuman beralkohol dengan kategori berat sebagian besar mempunyai tekanan darah beresiko $(13,8 \%)$ dan sisanya $(17,2 \%)$ mempunyai tekanan darah tinggi (hipertensi).

Secara keseluruhan sebagian besar responden sebanyak 39 orang $(44,8 \%)$ mempunyai tekanan darah beresiko (prehipertensi). Hasil uji korelasi sperman (Tabel 10) menunjukkan terdapat hubungan antara variabel jumlah konsumsi minuman beralkohol dengan kejadian hipertensi dengan korelasi yang cukup kuat yaitu 0,566 dengan nilai $\mathrm{p}=0,000(\mathrm{p}=0<0,05)$.

Tabel 9. Kejadian Hipertensi Berdasarkan Jumlah Konsumsi Minuman Beralkohol pada Tenaga Kerja Pariwisata di Kelurahan Legian

\begin{tabular}{|c|c|c|c|c|c|c|c|c|}
\hline \multirow{3}{*}{ Jumlah } & \multicolumn{6}{|c|}{ Kejadian Hipertensi } & \multirow{2}{*}{\multicolumn{2}{|c|}{ Total }} \\
\hline & \multicolumn{2}{|c|}{ Normal } & \multicolumn{2}{|c|}{ Beresiko (Prehipertensi) } & \multicolumn{2}{|c|}{ Tinggi } & & \\
\hline & $\mathbf{N}$ & $\%$ & $\mathbf{N}$ & $\%$ & $\mathbf{N}$ & $\%$ & $\mathbf{N}$ & $\%$ \\
\hline Konsumsi ringan & 21 & 14,1 & 21 & 14,1 & 0 & 0 & 42 & 28,3 \\
\hline Konsumsi sedang & 12 & 13,8 & 6 & 6,9 & 0 & 0 & 18 & 20,7 \\
\hline Konsumsi berat & 0 & 0 & 12 & 13,8 & 15 & 17,2 & 27 & 31,0 \\
\hline Total & 33 & 37,9 & 39 & 44,8 & 15 & 17,2 & 87 & 100 \\
\hline
\end{tabular}

Tabel 10. Hasil Uji Korelasi Sperman Antara Jumlah Konsumsi Minuman Beralkohol dengan Kejadian Hipertensi pada Tenaga Kerja Pariwisata di Kelurahan Legian

\begin{tabular}{llcl}
\hline Variabel independen & $\begin{array}{l}\text { Variabel } \\
\text { dependen }\end{array}$ & rs & p value \\
\hline $\begin{array}{l}\text { Jumlah Konsumsi } \\
\text { Minuman Beralkohol }\end{array}$ & $\begin{array}{l}\text { Kejadian } \\
\text { Hipertensi }\end{array}$ & 0,566 & 0,0001 \\
\hline
\end{tabular}

\section{PEMBAHASAN}

\section{Karakteristik Responden}

Responden dalam penelitian ini adalah tenaga kerja pariwisata yang masih aktif bekerja di hotel, cafe maupun bar di Kelurahan Legian. Responden pada penelitian ini merupakan individu yang bekerja dalam bidang pariwisata baik pelaksana langsung atau penyelenggara maupun berkontribusi dalam pengawasan dan memperoleh upah sesuai dengan posisi masing-masing. Pekerjaan dalam bidang pariwisata terdiri dari berbagai profesi yang diantaranya adalah bellboy, receptionist dan security yaitu yang bergerak pada bagian akomodasi hotel, sedangkan cook, waiter/waitress dan bartender bergerak pada bagian penyelengara makanan dan minuman khususnya minuman beralkohol.

Kondisi pekerjaan yang bersentuhan langsung dengan minuman beralkohol sangat berpengaruh pada kesehatan jangka panjang para tenaga kerja pariwisata, salah satunya dapat memicu kejadian hipertensi yang berujung pada stroke. Berdasarkan hasil penelitian yang dilakukan pada 87 responden yang merupakan tenaga pariwisata dengan berbagai bidang pekerjaan seperti bellboy, reseptionist, security, waiter/waitress dan bartender yang bekerja di salah satu hotel, cafe dan bar di Kelurahan Legian diperoleh bahwa sebagian besar responden bekerja pada bagian bartender sebanyak 28 responden $(32,2 \%)$ dengan rentang usia 17-25 tahun sebanyak 35 responden $(40,2 \%)$, dan tingkat pendidikan terakhir diploma sebanyak 44 responden $(50,6 \%)$. Berdasarkan hasil wawancara diperoleh informasi bahwa sebagian besar responden mengkonsumsi minuman beralkohol saat perayaan hari tertentu atau memperingati hari-hari tertentu. Responden biasanya mengkonsumsi minuman beralkohol di rumah, tempat kerja yaitu hotel, cafe atau bar lain yang menyediakan minuman beralkohol. Sebagian besar responden memperoleh minuman beralkohol dengan membeli sendiri, namun terdapat pula responden yang memperoleh minuman beralkohol dari tempat kerja dan teman.

\section{Jenis Minuman Beralkohol yang Dikonsumsi}

Berdasarkan hasil penelitian diperoleh bahwa pengolongan jenis minuman beralkohol yang paling banyak dikonsumsi responden adalah beer yaitu sebanyak 37 responden $(42,5 \%)$. Hal ini disebabkan karena ketersediaan beer dalam jumlah yang banyak di lingkungan masyarakat. beer merupakan salah satu 
minuman beralkohol dengan kandungan alkohol lebih rendah dibandingkan dengan wine dan spirits, namun konsumsi beer yang berlebihan dalam jangka waktu yang lama juga akan memberi dampak kurang menguntungkan bagi kesehatan.

Penelitian ini sejalan dengan hasil penelitian lain yang menyatakan bahwa sebagian besar jenis minuman beralkohol yang paling sering dikonsumsi oleh orang dewasa di Indonesia adalah beer. ${ }^{6}$ Konsumsi alkohol per kapita pada tahun 2000-2005 sebesar 0,005-0,06 liter alkohol murni. Beberapa jenis alkohol yang sering dikonsumsi di berbagai negara pada rentang tahun tersebut antara lain beer, wine, dan spirits. Beer dan wine merupakan salah satu dari berbagai minuman beralkohol yang memiliki kandungan alkohol yaitu sebesar 4,5\% dan 12,9\%. Bahan baku dari beer berasal dari gandum sedangkan bahan baku wine berasal dari anggur. Selain beer dan wine terdapat jenis minuman beralkohol dengan kadar alkohol yang lebih tinggi yaitu spirits yang biasa dikenal dengan brandy, wisky dan vodka dengan kadar alkohol.sebesar $41,1 \%$.

\section{Jumlah Konsumsi Minuman Beralkohol}

Penggolongan konsumsi minuman beralkohol, dibagi menjadi 3 golongan yaitu ringan $(0,29-6 \mathrm{ml}$ per hari), sedang $(6,30-29 \mathrm{ml}$ per hari), dan berat $(>29 \mathrm{ml}$ per hari). ${ }^{7}$ Berdasarkan hasil penelitian ini diperoleh sebagian besar responden mengkonsumsi alkohol dengan jumlah ringan yaitu $0,29-6 \mathrm{ml}$ per hari.

Penelitian lain yang dilakukan pada 71 reponden menunjukkan bahwa 24 reponden termasuk dalam mengkonsumsi alkohol dalam kategori berat. ${ }^{8}$ Dalam analisis chi square terdapat hubungan antara konsumsi alkohol berat dengan kejadian hipertensi. Bahwa peminum alkohol berat memiliki efek stroke hemoragik dimediasi oleh peningkatan tekanan darah. ${ }^{9}$

\section{Frekuensi Konsumsi Minuman Beralkohol}

Frekuensi konsumsi minuman beralkohol dikategorikan menjadi sering jika mengkonsumsi alkohol $\geq 3$ kali dalam per minggu dan kategori tidak sering jika mengkonsumsi alkohol $<3$ kali per minggu ${ }^{10}$. Pada penelitian ini menunjukkan sebanyak 49 responden mengkonsumsi alkohol dengan frekuensi sering ( $3 \mathrm{x}$ seminggu atau lebih). Penelitian lain menyatakan responden yang mengkonsumsi minuman beralkohol satu bulan terakhir $\geq 2$ gelas/hari dapat meningkatkan hipertensi, dibandingkan tidak mengkonsumsi sama sekali ${ }^{11}$.

\section{Hubungan Pola Konsumsi Minuman Beralkohol dengan Kejadian Hipertensi}

Pola konsumsi alkohol adalah jenis, jumlah dan frekuensi minuman beralkohol yang dikonsumsi seseorang atau kelompok orang pada waktu tertentu.
Alkohol merupakan suatu hasil fermentasi karbohidrat oleh mikroorganisme dalam keadaan anaerobik. Dalam bidang medis alkohol biasanya digunakan sebagai bakterisida, fungisida dan virusida. Namun penggunaan atau konsumsi minuman alkohol yang berlebih pada masyarakat dapat berdampak pada penurunan kesehatan yang akan mengganggu dan merusak fungsi beberapa organ yaitu salah satunya adalah hati, fungsi hati akan terganggu sehingga mempengaruhi kinerja dan fungsi jantung. Gangguan fungsi jantung yang terjadi pada akhirnya menyebabkan hipertensi. Hal ini terjadi karena alkohol merangsang epinefrin atau adrenalin yang membuat arteri mengecil dan menyebabkan penimbunan air dan natrium,

Peningkatan konsumsi alkohol dalam jangka waktu yang lama akan berpengaruh pada peningkatan kadar kortisol dalam darah sehingga aktivitas renninangiotensin aldosteron system (RAAS) akan meningkat yaitu sistem hormon yang mengatur keseimbangan tekanan darah dan cairan dalam tubuh. Selain itu, jika seseorang yang mengkonsumsi alkohol maka volume sel darah merah di dalam tubuhnya akan meningkat. Hal ini akan meningkatkan viskositas darah yang dapat meningkatkan tekanan darah. faktor resiko yang dapat menyebabkan terjadinya hipertensi yaitu status gizi, riwayat keluarga, merokok, stres, dan konsumsi alcohol. ${ }^{12}$

Berdasarkan hasil uji korelasi sperman antara pola konsumsi minuman beralkohol yang meliputi jenis, jumlah dan frekuensi minuman beralkohol dengan kejadian hipertensi menunjukkan bahwa terdapat hubungan yang signifikan antara kedua variabel tersebut yaitu dengan $\mathrm{p}=0,000 \quad(\mathrm{p}<0,005)$ dengan angka korelasi $r_{s}=0,433$ (jenis minuman dan kejadian hipertensi) dan $r_{s}=0,566$ (jumlah konsumsi dan kejadian hipertensi). Penelitian yang dilakukan di Suku Bajo juga menunjukkan bahwa salah satu faktor resiko penyebab hipertensi pada nelayan adalah konsumsi alkohol. Pada hasil penelitian tersebut menyebutkan bahwa konsumsi alkohol yang berlebih yaitu dengan minimal 1 gelas atau lebih setiap hari memiliki resiko 7,917 kali mengalami hipertensi dibandingkan dengan responden yang mengkonsumsi kurang dari satu gelas perhari. ${ }^{13}$ Penelitian lain yang dilakukan pada responden pada usia 18-40 tahun di Desa Jatikusuma menujukkan bahwa terdapat hubungan yang bermakna antara konsumsi minuman beralkohol dengan kejadian prehipertensi.

\section{SIMPULAN}

Hasil penelitian menunjukkan jenis minuman beralkohol yang paling banyak dikonsumsi adalah beer dengan persentase $40,2 \%$. Sebanyak $48,3 \%$ responden mengkonsumsi minuman beralkohol dengan jumlah 
ringan dan sebanyak 56,3\% responden sering mengkonsumsi minuman beralkohol. Terdapat hubungan yang signifikan antara jenis minuman dan kejadian hipertensi $\left(\mathrm{r}_{\mathrm{s}}=0,433\right)$ dan jumlah konsumsi dan kejadian hipertensi $\left(r_{s}=0,566\right)$.

\section{DAFTAR PUSTAKA}

1. Komaling, J., Suba, BT, dan Wongkar, D. Hubungan mengkonsumsi alkohol dengan kejadian hipertensi pada laki-laki di Desa Tompasobaru II Kecamatan Tompasobaru Kabupaten Minahasa Selatan. E-jurnal keperawatan. 2013; 1:1-7.

2. Mukhibbin, A. Dampak kebiasaan merokok, minuman alkohol dan obesitas terhadap kenaikan tekanan darah pada masyarakat di Desa Gonilan Kecamatan Kartasura Kabupaten Sukoharjo. Skripsi. Fakultas Farmasi Universitas Muhammadiyah Surakarta. Surakarta; 2013.

3. Badan Penelitian dan Pengembangan Kesehatan Kementerian RI. Laporan hasil riset kesehatan dasar (Riskesdas) Provinsi Bali tahun 2013. 2013.

4. Montol, A., Pascoal, M. E., dan Pontoh, L. Faktor resiko terjadinya hipertensi pada usia produktif di wilayah kerja puskesmas Lasot kota Tomohon. Gizido. 2015; 7(1):16-30.

5. Russ, M., Kepel, B. J., dan Umboh, J. M. Hubungan antara konsumsi alkohol dan kopi dengan kejadian hipertensi pada laki-laki di desa Ongkaw Dua kecamatan Sinosayang kabupaten Minahassa Selatan. Kesmas. 2016; 5:65-72.

6. Erick. Hubungan antara konsumsi alkohol dengan prevalensi tuberkulosis paru pada pasien diabetes melitus tipe 2 di Rumah Sakit Cipto Mangunkusumo tahun 2010. Skripsi. Fakultas Kedokteran Universitas Indonesia; 2012.
7. Vitahealth. Hipertensi. Penerbit PT Gramedia Pustaka Utama, Jakarta; 2005.

8. Situmorang, PR. Faktor-faktor yang berhubungan dengan kejadian hipertensi pada penderita rawat inap di Rumah Sakit Umum Sari Mutiara Medan tahun 2014. Jurnal Ilmiah Keperawatan. 2015; 1 (1):67-72.

9. Khosuma, E., Kembuan, M., dan Karema, W. Gambaran pengetahuan remaja mengenai bahaya alkohol dengan stroke. Jurnal e-Biomedik. 2013; 1(1): 215-219.

10. Ainun, AS., Sidik, AS., dan Rismayanti. Hubungan gaya hidup dengan kejadian hipertensi pada mahasiswa di lingkungan kesehatan Universitas Hasanuddin. Skripsi. Universitas Hasanuddin; 2014.

11. Robin, GD., Primayanti, ID., dan Dinata, IM. Prevalensi hipertensi pada mahasiswa semester VI Program Studi Pendidikan Dokter di Fakultas Kedokteran Universitas Udayana. E-Jurnal Medika. 2017; 6(2):1-16.

12. Elvivin, Lestari, H., dan Ibrahim, K. Analisis faktor resiko kebiasaan mengkonsumsi garam, alkohol, kebiasaan merokok dan minum kopi terhadap kejadian hipertensi pada nelayan suku bajo di Pulau Tasipi kabupaten Muna Barat tahun 2015. Ilmiah Mahasiswa Kesehatan Masyarakat. 2016; 1(3):1-12.

13. Puspitasari, S. D., Rasmaliah, dan Ashar, T. Faktor-faktor yang berhubungan dengan kejadian pre hipertensi pada usia 18-40 tahun di Desa Jati Kesuma Kecamatan Namo Rambe Kabupaten Deli Serdang. Gizi, Kesehatan Reproduksi \& Epidimiologi. 2015; 1(4):1-8. 